\title{
Pengembangan media pembelajaran $e$-book berdasarkan hasil riset elektroforesis 2-d untuk mengukur kemampuan berpikir kreatif mahasiswa
}

Dwi Mentari*, Sumpono, Aceng Ruyani

Pascasarjana Pendidikan IPA FKIP Universitas Bengkulu, Bengkulu

*Email: dwimentari40@gmail.com

\begin{abstract}
ABSTRAK
Penelitian ini bertujuan untuk mengemas hasil profil protein hati Mus musculus dengan elektroforesis dua dimensi ke dalam buku elektronik (e-book), dan mengetahui kemampuan berpikir kreatif mahasiswa terhadap implementasi pembelajaran menggunakan media e-book. Metode yang digunakan dalam penelitian ini adalah penelitian pengembangan (Development Research). Hasil penelitian ini yaitu media pembelajaran $e$-book yang dibangun berdasarkan hasil riset secara struktural terdiri dari; a) pendahuluan, b) materi isi elektroforesis, c) analisis hasil penelitian, d) kesimpulan, e) evaluasi, dan f) biodata penulis. Setelah e-book diimplementasi terhadap mahasiswa sebanyak 30 orang menunjukkan bahwa mahasiswa yang berpikir sangat kreatif berjumlah 19 orang (63\%), mahasiswa berpikir kreatif 7 orang $(23,3 \%)$, dan mahasiswa berpikir cukup kreatif 3 orang (13,3\%).
\end{abstract}

Kata kunci : E-book; elektroforesis 2-D; kemampuan berpikir kreatif.

\section{PENDAHULUAN}

Penelitian mengunakan elektroforesis di lingkungan Universitas Bengkulu cukup diminati, terlihat bahwa sejak 2012 terdapat minimal empat orang mahasiswa melakukan penelitian mengunakan elektroforesis (Ismi, 2016). Besarnya minat mahasiswa melakukan penelitian mengunakan elektroforesis belum ditunjang dengan adanya petunjuk dan buku panduan kerja elektroforesis yang memadai. Sehingga banyak mahasiswa yang mengalami kebingungan terhadap prosedur elektroforesis diawal penelitiannya. Berdasarkan kondisi tersebut maka perlu dikembangkan media pembelajaran yang mencakup tutorial tentang elektroforesis untuk menunjang minat dan memfasilitasi mahasiswa yang akan melakukan penelitian menggunakan elektroforesis.

Salah satu media pembelajaran mahasiswa yang mengimplementasikan perkembangan teknologi dan komunikasi dengan interaksi pengguna yang sedang dikembangkan saat ini adalah buku digital atau dikenal dengan e-book (Hartanti, 2013). Buku digital, atau disebut juga e-book merupakan sebuah publikasi yang terdiri dari teks, gambar, maupun suara dan dipublikasikan dalam bentuk digital yang dapat dibaca di komputer maupun perangkat elektronik lainnya seperti android, atau tablet
(Andikaningrum et al. 2014). E-book atau electronic book (atau juga digital book) adalah evolusi dari buku cetak yang biasa kita baca sehari-hari (Subiyantoro,2014).

Salah satu aplikasi untuk membuat ebook ini yaitu Electronic publication (E-book) merupakan salah satu format buku digital yang disepakati oleh International Digital Publishing Forum (IDPF) pada Oktober 2011. E-book menggantikan peran Open eBook sebagai format buku terbuka. Ebook terdiri atas file multimedia, html5, css, xhtml, xml yang dikemas dalam satu file (Seameo Seamolec, 2014). Sehingga dari media pembelajaran ini dapat menarik perhatian dan kemampuan berpikir mahasiswa.

Ada banyak jenis kemampuan berpikir manusia, untuk kategori mahasiswa kemampuan berpikir tingkat tinggi dirasa cocok untuk mengukur tingkat kemampuan mahasiswa. Salah satu kemampuan berpikir tingkat tinggi yaitu kemampuan berpikir kreatif (Widowati, 2013). LTSIN (2004) dalam Wattimena et al (2014) menyatakan bahwa berpikir kreatif adalah proses (bukan hasil) untuk menghasilkan ide baru dan ide itu merupakan gabungan dari ide-ide yang sebelumnya belum disatukan. Menurut Fisher (1995), kreativitas adalah kemampuan dan sikap seseorang untuk membuat produk yang baru. Kreativitas bukanlah mengadakan sesuatu yang tidak ada menjadi ada (Siswono dan Novitasari, 
2003), akan tetapi kreativitas adalah kemampuan untuk menghasilkan ide-ide baru dengan cara membuat kombinasi, membuat perubahan, atau mengaplikasikan ide-ide yang ada pada wilayah yang berbeda (Harris, 1998). Dari pendapat di atas, dapat diartikan bahwa berpikir kreatif adalah aktivitas berpikir agar muncul kreativitas pada seseorang, atau berpikir untuk menghasilkan hal yang baru bagi dirinya. Sedangkan Guilford dalam Munandar (2009) menyebutkan lima indikator berpikir kreatif, yaitu:

- Kepekaan (problem sensitivity), adalah kemampuan mendeteksi, mengenali, dan memahami serta menanggapi suatu pernyataan, situasi, atau masalah;

- Kelancaran (fluency), adalah kemampuan untuk menghasilkan banyak gagasan;

- Keluwesan (flexibility), adalah kemampuan untuk mengemukakan bermacam-macam pemecahan atau pendekatan terhadap masalah;

- Keaslian (originality), adalah kemampuan untuk mencetuskan gagasan dengan cara-cara yang asli, tidak klise, dan jarang diberikan kebanyakan orang;

- Elaborasi (elaboration), adalah kemampuan menambah suatu situasi atau masalah sehingga menjadi lengkap, dan merincinya secara detail, yang didalamnya terdapat berupa tabel, grafik, gambar, model dan katakata.

\section{METODE PENELITIAN}

Metode yang digunakan dalam penelitian ini adalah metode penelitian pengembangan (Development Research), karena bertujuan untuk mengembangkan suatu produk berdasarkan kebutuhan yang terdiri hasil analisis data suatu penelitian yang dilakukan sebelumnya (Suryanto dan Rahmat, 2006).

\section{Prosedur Penelitian}

Prosedur penelitian yang diterapkan dalam penelitian ini adalah prosedur penelitian pengembangan produk multimedia pembelajaran yang dikembangkan oleh Suheri (2006) dan Sutopo dalam Soenarto (2006). Prosedur penelitian disajikan pada Diagam berikut.

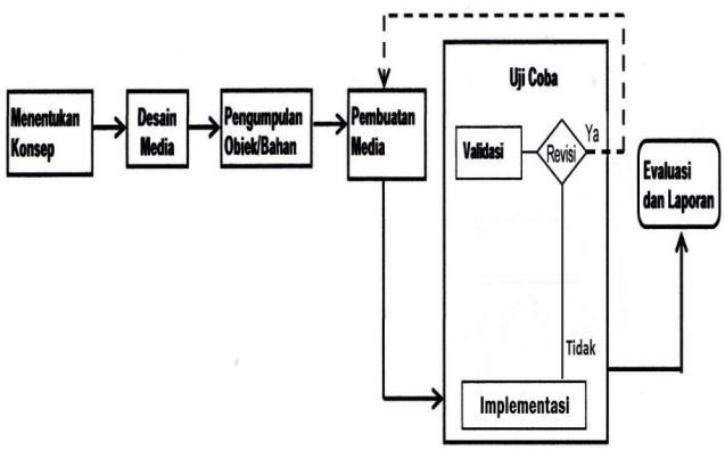

Gambar 1. Diagam prosedur penelitian

Mendeskripsikan struktur progam (storyboard),

Dalam penyusunan $E$-book berbasis riset ini, dibagi menjadi:

- Pendahuluan yang didalamnya mencakup kata pengantar, daftar isi, Latar belakang pembelajaran, tujuan pembelajaran, deskripsi singkat, dan petunjuk penggunaan media.

- Pembelajaran yang didalamnya terdiri dari elektroforesis, elektroforesis dimensi 1 ( prinsip kerja, alat dan bahan), elektroforesis dimensi 2 (prinsip kerja, alat dan bahan). Analisis hasil penelitian.

- Penutup terdiri atas kesimpulan, saran, daftar pustaka, dan biodata pembuat

- Evaluasi berupa tes kemampuan berpikir kreatif mahasiswa.

\section{Analisis data kemampuan berpikir kreatif mahasiswa}

\section{Analisis hasil Tes dan angket Kemampuan} berpikir Kreatif

Perhitungan tes kemampuan berpikir kreatif mahasiswa

$$
\text { nilai }=\frac{n}{N} \times 100
$$

Rumus rentang aspek pembelajaran berpikir kreatif mahasiswa:

Rentang $=\frac{\text { Skor maksimum }- \text { skor minimum }}{\text { Jumlah Kategori }}$ 
Deskripsi kualitatif untuk soal tes kemampuan berpikir kreatif mahasiswa:

$25<\mathrm{P} \leq 42,5=$ Kurang Kreatif

$43,5<\mathrm{P} \leq 61,5=$ Cukup Kreatif

$61,5<\mathrm{P} \leq 80,25=$ Kreatif

$81,25<\mathrm{P} \leq 100=$ Sangat Kreatif

Tingkat ketuntasan mahasiswa dihitung dengan teknik analisis persentase:

$$
p=\frac{\sum n i}{\sum n} \times 100 \%
$$

Keterangan:

$\mathrm{p}=$ ketuntasan klasikal

$\sum n i=$ jumlah mahasiswa kreatif secara individual

$\sum n=$ jumlah total mahasiswa

\section{HASIL DAN PEMBAHASAN}

Hasil yang didapat berupa media ebook dengan tampilan buku digital. Media Ebook dibuat agar mahasiswa mampu belajar secara mandiri Wahono (2006). Adapun deskripsi produk media Ebook adalah sebagai berikut:

Tabel 1. Deskripsi produl media Ebook

\begin{tabular}{|l|l|}
\hline \multicolumn{1}{|c|}{ Jenis produk } & \multicolumn{1}{|c|}{ Ebook } \\
\hline Desain produk & $\begin{array}{l}\text { Media pembelajaran buku } \\
\text { digital }\end{array}$ \\
\hline Fungsi produk & $\begin{array}{l}\text { Media pembelajaran } \\
\text { Ebook aalisis hasil } \\
\text { elektroforesis 2-d }\end{array}$ \\
\hline Format program & Interaktif \\
\hline Ukuran file & $\pm 400 \mathrm{Mb}$ (keseluruhan). \\
\hline Format file & Ebook \\
\hline Software & $\begin{array}{l}\text { Sigil } \\
\text { Calibre } \\
\text { e-book reader }\end{array}$ \\
\hline
\end{tabular}

Dalam penyusunan E-Book berbasis riset ini, dibagi menjadi:

- Pendahuluan yang didalamnya mencakup kata pengantar, daftar isi, Latar belakang pembelajaran, tujuan pembelajaran, deskripsi singkat, dan petunjuk penggunaan media.

- Pembelajaran yang didalamnya terdiri dari elektroforesis, elektroforesis dimensi 1 ( prinsip kerja, alat dan bahan), elektroforesis dimensi 2 (prinsip kerja, alat dan bahan). Analisis hasil penelitian. Penutup terdiri atas kesimpulan, saran, daftar pustaka, dan biodata pembuat.

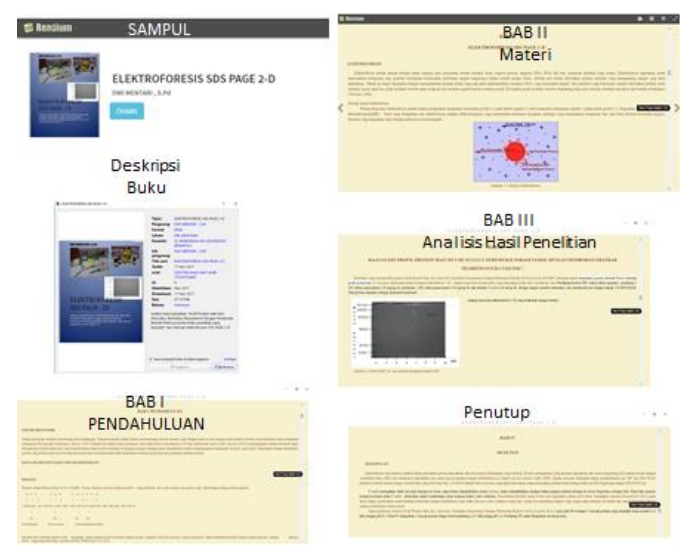

Gambar 2. Kerangka media Ebook yang telah dikembangkan

Evaluasi, berupa tes kemampuan berpikir kreatif mahasiswa.

Tabel 2. Hasil analisis tes kemampuan berpikir kreatif mahasiswa

\begin{tabular}{|l|c|c|}
\hline Kategori & $\begin{array}{c}\text { Jumlah } \\
\text { mahasiswa } \\
\text { berdasarkan } \\
\text { kategori }\end{array}$ & $\begin{array}{c}\text { Persentase } \\
\text { ketuntasan } \\
\text { berpikir kreatif } \\
\text { mahasiswa }\end{array}$ \\
\hline $\begin{array}{l}\text { Sangat } \\
\text { kreatif }\end{array}$ & 19 & $63,3 \%$ \\
\hline Kreatif & 7 & $23,3 \%$ \\
\hline $\begin{array}{l}\text { Cukup } \\
\text { kreatif }\end{array}$ & 4 & $13,3 \%$ \\
\hline
\end{tabular}

Dari tabel 2, hasil dari analisis deskriptif tes kemampuan berpikir mahasiswa didapatkan, dari 30 orang mahasiswa 19 orang dikategorikan sangat kreatif, 7 orang dikategorikan kreatif, dan 4 orang dikategori cukup kreatif.

Hasil presentase menunjukkan sebanyak $64 \%$ mahasiswa berpikir sangat kreatif, $23 \%$ 
berpikir kreatif, dan $13 \%$ cukup kreatif. Ini berarati secara persentase $87 \%$ mahasiswa dikelas mampu berpikir kreatif setelah melakukan pembelajaran dengan menggunakan media pembelajaran Ebook.

\section{KESIMPULAN}

Media pembelajaran Epun yang kembangka berupa buku digital yang yaitu meggunakan software Sigil dan Ebook reader secara struktural mencakup: Bab I Pendahuluan, Bab II Elektroforesis, Bab III Analisis hasil penelitian, Baba IV kesimpulan, evaluasi, dan biodata penulis. Kemampuan berpikir kreatif mahasiswa diukur dengan tes dan lembar angket. Dari hasil tes didapatkan mahasiswa yang berpikir sangat kreatif berjumlah 19 orang dengan persentase 63\%, mahasiswa berpikir kreatif 7 orang dengan persentase $23,3 \%$, dan mahasiswa berpikir cukup kreatif 3 orang dengan persentase $13,3 \%$.

\section{UCAPAN TERIMA KASIH}

Terima kasih kami sampaikan kepada pengelola Sumber Belajar Ilmu Hayati (SBIH) Ruyani yang telah menyokong dana dan mendukung penelitian hingga selesai.

\section{DAFTAR PUSTAKA}

Andikaningrum, L., Damayanti, W., \& Dewi, C. (2014). Efektivitas E-Book Berbasis Multimedia Menggunakan Flip Book Maker sebagai Media Pembelajaran dalam Meningkatkan Keaktifan Belajar Siswa (Studi Kasus pada Mata Pelajaran TIK Kelas XI SMA Kristen Satya Wacana Salatiga) (Doctoral dissertation, Program Studi Pendidikan Teknologi Informasi dan Komunikasi FTI-UKSW).

Fisher, R. (1995). Teaching Children to Think. London: Stanley Thornes Ltd.

Harris, R. (1998). Introduction to Creative Thinking. [online]. Tersedia: http://www.virtualsalt.com/it dt.htm. (diakses 10 November 2017)

Hartanti, D. (2013). Media Pembelajaran (Ebook). Pendidikan Tehnik dan

\section{Arsitektur Universitas Pendidikan Indonesia.}

Ismi, Mutiara Gusnita. 2016. Pemulihan profil protein otak Mus.msculus terinduksi merkuri klorida dengan pemberian ekstrak Etlingera hemisphaerica. Bengkulu : Universitas Bengkulu

Munandar, U. 2009. Pengembangan Kreativitas Anak Berbakat. Jakarta: Rineka Cipta

Siswono, T. Y. E., \& Novitasari, W. (2007). Meningkatkan kemampuan berpikir kreatif siswa melalui pemecahan masalah tipe what's another way. Jurnal Trasformasi, 1(1).

Southeast Asian Ministers of Educatioan Organization Regional Open Learning Centre (SEAMEO SEAMOLEC). 2014. Buku Sumber:Buku Digital. Pelatihan buku digital 26 maret 2014.

Subiyantoro, Eko. 2014. Menapak di Era Digital denganMemasyarakatkan Buku Digital. http://www.vedcmalang.com/pppptkboem lg/index.php/menuutama/teknologiinf ormasi/1114-eko-subiyantorowidyaiswara-muda-departementeknologiinformasi-pppptk-boe-malang (diakses pada 15 mei 2017)

Suheri (2006) dan Sutopo dalam Soenarto (2006). Soenarto, 2006. Metodologi Penelitian Pengembangan Untuk Kualitas Pembelajaran. Makalah Pelatihan Metodologi Penelitian. Jakarta: Direktoran Jendral Pendidikan Tinggi dan Departemen Pendidikan Nasional

Wattimena, H. S., Suhandi, A., \& Setiawan, A. (2014). Profil Penyelenggaraan Praktikum Fisika Sekolah sebagai Penyiapan Mengembangkan Kreativitas Calon Guru. Jurnal Pendidikan MIPA Universitas Lampung, 15(2).

Widowati, A. (2013). Brainstorming Sebagai Alternatif Pengembangan Berfikir Kreatif Dalam Pembelajaran Sains Biologi. Jurnal Biologi Edukasi, 2(3), 17-22. 